\title{
$\mathrm{ADC} 12 / 5052$ アルミニウム合金異材摩擦攪拌接合継手における 引張強さと断面硬さ分布の関係
}

\author{
小久保 正史 $*$ *** 高山 善匡 ${ }^{* *}$ ・和井 伸一 * \\ 金内 良夫 $*$. 加藤 一 $* *$ * 平野 聡 $* * *$
}

Journal of Japan Institute of Light Metals, Vol. 58, No. 4 (2008), pp. 146-150

\section{Relation of tensile strength and hardness distribution in friction stir welded joints of ADC12/5052 dissimilar aluminum alloys}

\begin{abstract}
Masafumi KOKUBO****, Yoshimasa TAKAYAMA**, Shinichi KAZUI* Takao KANEUCHI*, Hajime KATO** and Satoshi HIRANO***

$\mathrm{ADC} 12$ and 5052 dissimilar aluminum alloys have been connected by friction stir welding (FSW). The temperatures at the stir zone and at four points on each outside of the joint line were measured during FSW in various conditions. After FSW, the tensile test was carried out in the direction perpendicular to the joint line. Tensile strength did not depend on the traveling speed, and indicated an almost constant value by about $88 \%$ of mother material strength. However, the necking feature in the breaking part was influenced by the traveling speed. That is, the necking was caused at low traveling speeds of FSW while it was hardly caused at high traveling speeds. The two-dimensional hardness distribution in the WD section was measured for various FSW conditions. The material flow with stirring and the spatial difference of the hardness distribution appeared at various traveling speeds. The stirred region consisting of stir zone and thermomechanical affected zone and the softened part in the stir zone were wider in the 5052 side at lower traveling speed. Softening in the 5052 side was scarcely observed in high traveling speeds. Moreover, the difference of softening in this 5052 was attributed to a difference in the heat input by changing the traveling speed.
\end{abstract}

(Received October 4, 2007 Accepted January 7, 2008)

Keywords: friction stir welding, hardness distribution, aluminum alloys, dissimilar alloys, heat input

\section{1. 緒言}

摩擦攪拌接合（Friction Stir Welding：以下 FSW）は，1991 年に英国で開発 ${ }^{1)}$ されて以来，従来の溶接法にない優れた特 徴を持つ革新的な固相接合技術として注目され，鉄道車両， 航空機，船舶，自動車，土木構造物を中心に，多くの分野の

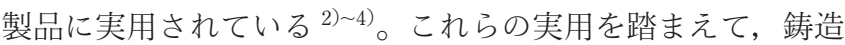
材と展伸材との FSW 異材接合に関する研究むなされて (る ${ }^{5) ~ 8)}$ 。著者らは，アルミニウム合金ダイカスト $\mathrm{ADC12}$ 5052 アルミニウム合金展伸材の FSW 継手に打ける組織と接 合強さの関係を調へ，両合金の配置により接合部断面組織が 明確に異なること等を明らかにした ${ }^{9)}$ 。すなわち，前進側 (Advancing side; AS) に 5052, 後退側 (Retreating side; RS) に ADC12 を配した継手（以下 AS/RS の順で表記する）にお いて，両者を入替えた配置の継手に比べて，攪拌部の異材接 合界面の凹凸が激しく，両合金がよりよく混合されている組 織を呈した。この結果は, 接合速度が異なる条件での組織の 違いと類似しており, 配置の違いが接合時の温度の差を生じ

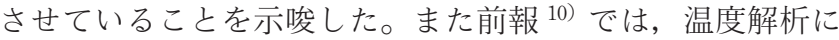

おいて，接合速度と入熱量，材料の温度，攪拌に消費される 仕事について検討した。配置の違いによる温度差は, FSW 時 の攪拌状況に影響を与え, さらに材料組織形成に影響を与 え，結果として接合部の強さを左右すると推測される。しか しながら，既報 ${ }^{9)}$ のように，接合速度と材料配置の違いは継 手の引張強さに現れていない。

そこで, 本研究では, 材料組織には明確な差を生じさせな がら継手強度には明確な差を与えない FSW 条件の影響を明 らかにするため，接合中の温度を測定しながら異材の FSW を行った。また, 継手の引張試験を行い, 攪拌部断面の硬さ 分布を測定した。これらの結果から, FSW の材料配置, 接合 速度の違いによる攪拌の程度, 入熱の傾向に着目し, 引張強 さと硬さ分布との関係を詳細に検討した。

\section{2. 実 験 方 法}

供試材料には板厚 $2.3 \mathrm{~mm}$ のアルミニウム合金ダイカスト （ADC12）とアルミニウム合金展伸材（5052-H34）を使用し た。Table 1 に使用したアルミニウム合金の化学組成を示す。 $\mathrm{ADC} 12$ と 5052 の熱伝導率はそれぞれ $94,137 \mathrm{~W} \cdot \mathrm{m}^{-1} \cdot \mathrm{K}^{-1}$ で

*日立金属(森）（～360-0843＼cjkstart埼玉県熊谷市三ヶ尻 6010)。Hitachi Metals, Ltd. (6010 Mikajiri, Kumagaya-shi, Saitama 360-0843).

**宇都宮大学工学部機械システム工学科（宇都宮市）。Department of Mechanical Systems Engineering, Utsunomiya University (Utsunomiyashi, Tochigi).

***(株)日立製作所（日立市)。Hitachi, Ltd. (Hitachi-shi, Ibaraki) 
Table 1 Chemical compositions of specimens (mass\%)

\begin{tabular}{|c|c|c|c|c|c|c|c|c|c|c|}
\hline & $\mathrm{Cu}$ & $\mathrm{Si}$ & $\mathrm{Mg}$ & $\mathrm{Zn}$ & $\mathrm{Fe}$ & Mn & $\mathrm{Ni}$ & $\mathrm{Sn}$ & $\mathrm{Cr}$ & $\mathrm{Al}$ \\
\hline $\mathrm{ADC} 12$ & $1.5 \sim 3.5$ & $9.6 \sim 12.0$ & $\sim 0.3$ & $\sim 3.0$ & $\sim 1.3$ & $\sim 0.5$ & $\sim 0.5$ & $\sim 0.3$ & - & Bal. \\
\hline 5052 & $0.01 \sim 0.02$ & 0.08 & $2.50 \sim 2.61$ & $0.17 \sim 0.22$ & $0.27 \sim 0.28$ & $0.01 \sim 0.02$ & - & - & $\sim 0.01$ & Bal. \\
\hline
\end{tabular}

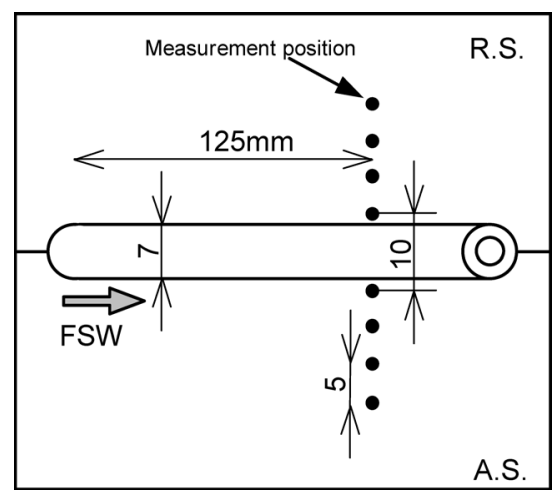

Fig. 1 Schematic illustration showing direction of friction stir welding (FSW) and positions of temperature measurement.

ある ${ }^{11)}$ 。FSW は 2 枚の板を突合せて行った。FSW に使用し

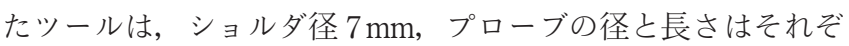
れ $3 \mathrm{~mm}, 2 \mathrm{~mm}$ である。ッールの前進角は 3 度とした。回転 数は $2000 \mathrm{rpm}$ とし, 接合速度は $125 \sim 2000 \mathrm{~mm} / \mathrm{min}$ （2.08 33.3 mm/s）の範囲とした。Fig. 1 に FSW 方向と温度 測定位置の概略図を示す。材料表面温度は接合開始点から $125 \mathrm{~mm}$ の位置で, 突合せ線から $5 \mathrm{~mm}$ ごとに両側 8 箇所の表 面を薄型 K 熱電対により測定した。FSW 後, 接合方向と垂 直で FSW 部が引張試験片平行部中央になるように, 平行部 幅 $6 \mathrm{~mm}$, 平行部長さ $32 \mathrm{~mm}$ の試験片を作製し引張試験を 行った。また, FSW 後の断面をマイクロビッカース硬さ試験 し, FSW 部の硬さを測定した。

\section{3. 結果と考察}

\section{1 引張試験}

Fig. 2 に引張強さおよび破断伸びと接合速度の関係を示す。 $1500,2000 \mathrm{~mm} / \mathrm{min}$ の接合速度の断面観察において，微小な 欠陷が見られたが，引張強さは，125～2000 mm/min の接合速 度範囲, AS と RS の材料の配置による变化がほとんど見られ ず，全条件でほぼ一定の約 $230 \mathrm{MPa}$ となった。5052-H34の母 材引張強さは $260 \mathrm{MPa}$ であるので, 継手効率は約 $88 \%$ であっ た。一方，伸びの值は，ばらつきはあるものの，接合速度の 増加に伴い減少傾向が見られた。既報 ${ }^{9)}$ の接合速度 500 1500 mm/min の条件においてほぼ一定の引張強さが得ら れていたが, 本研究でより低速度側の $125,250 \mathrm{~mm} / \mathrm{min}$, さ らに高速度側 $2000 \mathrm{~mm} / \mathrm{min}$ の条件で FSW を実施し, ょり広 範囲の接合速度条件に沶いて, 引張強さが一定であることが 確認された。Fig. 3 に引張試験で破断した破断部のマクロ組 織を示す。5052/ADC12 の配置では， $125 \mathrm{~mm} / \mathrm{min} \sim 2000$ $\mathrm{mm} / \mathrm{min}$ の全接合速度で攪拌部 AS の 5052 側で破断した。こ れに対して，ADC12/5052の配置では， $125 \mathrm{~mm} / \mathrm{min} \sim 1000$ $\mathrm{mm} / \mathrm{min}$ の接合速度で覺找部 RS の 5052 側で破断し， 1500, $2000 \mathrm{~mm} / \mathrm{min}$ の接合速度では攪拌部 AS の ADC12 側の内部欠

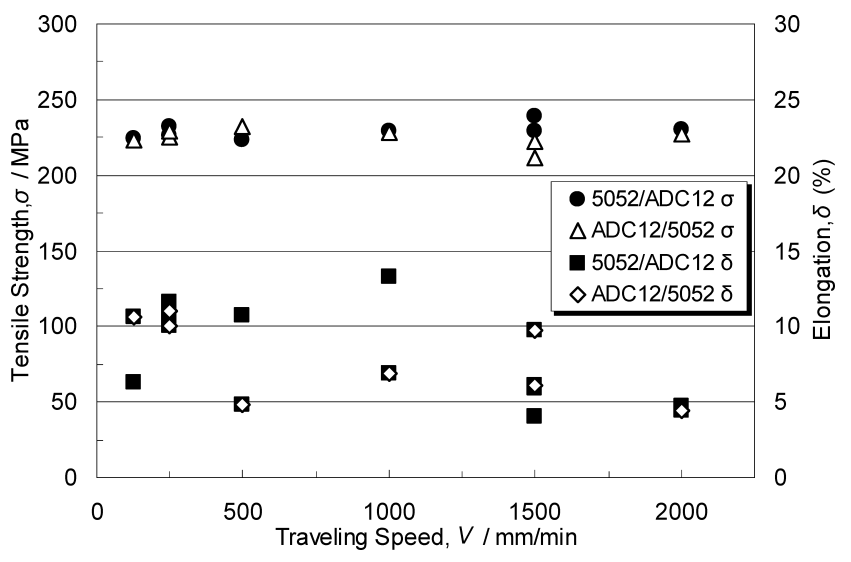

Fig. 2 Relations between traveling speed and tensile strength, and elongation in dissimilar FSWed joints of 5052/ADC12 and ADC12/5052 aluminum alloys. A part of data in the traveling speed range from 500 to $1500 \mathrm{~mm} / \mathrm{min}$ is quoted from a previous paper ${ }^{9)}$.

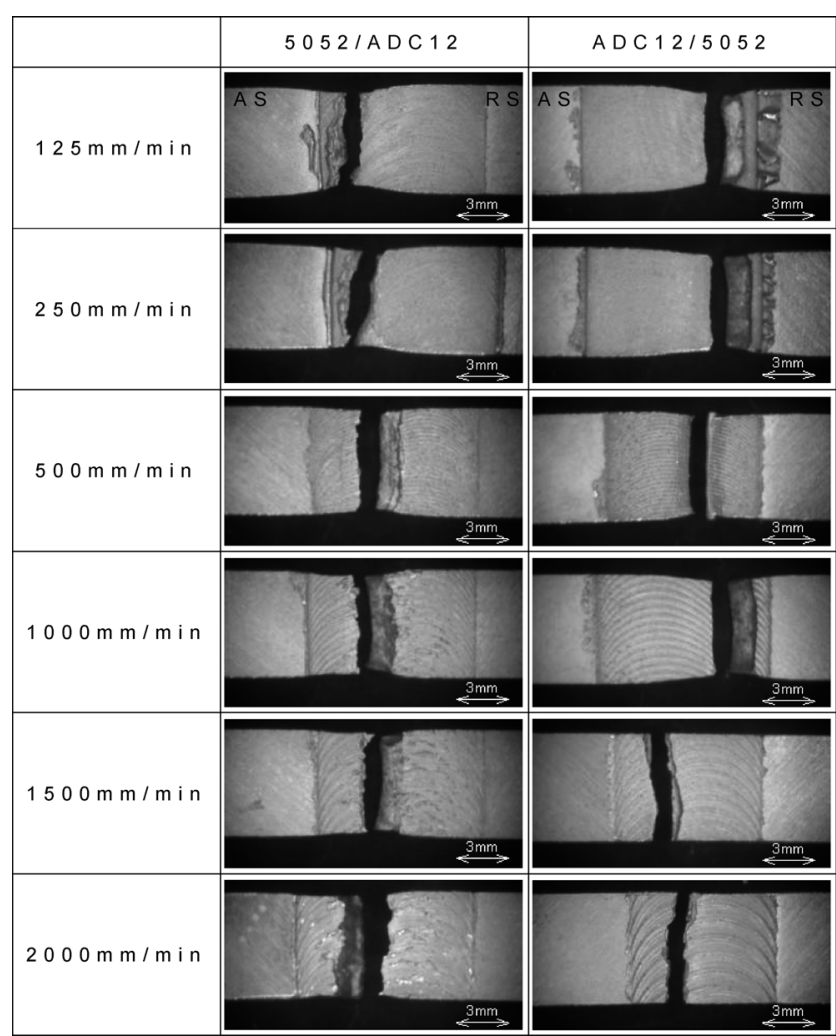

Fig. 3 Fracture part of tensile specimen after failure.

陥で破断した。引張試験では, 後述の硬さ分布で最む硬さの 小さい場所であった FSW 攪拌部の 5052 側で破断した。破断 部のネッキングを比較すると, 低接合速度 $(125 \mathrm{~mm} / \mathrm{min})$ の 条件で幅方向に5052/ADC12 の配置では $15.4 \%, A D C 12 / 5052$ の配置では $18.5 \%$ 絞れているのに対し，高接合速度（2000 
$\mathrm{mm} / \mathrm{min}$ ）の条件では5052/ADC12 の配置では $9.2 \%$, $\mathrm{ADC} 12 / 5052$ の配置ではほとんど变形がなかった（絞り：ほぼ $0 \%)$ 。低接合速度の方が明らかにくびれの程度が大きいこと がわかった。ネッキングは主に 5052 側で生じていた。伸びの 值に大きな差が見られなかった原因は，接合継手の攪找部に おいて，より硬い ADC12 が 5052 の変形を拘束しているため と考えられた。

\section{2 断面硬さ分布}

次に，この引張破断時のネッキングの違いを硬さ測定によ り詳細に検討した。Fig. 4 にマイクロビッカース硬さ試験後 の断面の光学顕微鏡写真と, 2 次元的な硬さ分布の一例（125 $\mathrm{mm} / \mathrm{min}$ ）を示す。(なお, Fig. 4 およびFig. 5 中, 白点は測 定不良点である。）FSW した（a）5052/ADC12 および（b） $\mathrm{ADC} 12 / 5052$ の配置の継手である。圧痕の間隔は，継手の幅 方向 $0.5 \mathrm{~mm}$, 厚さ方向 $0.4 \mathrm{~mm}$ である。硬さ分布図の上面は, 試料断面の上面からおおむね $0.4 \mathrm{~mm}$ 程度離れており，FSW 部上面之は一致しない。写真では継手両側の材料の違いが, コントラストの違いとして現れた。硬さ分布では，5052が約 60 80 HV，ADC12 が約 80 120 HV の硬さを示した。硬さ分 布図横軸中央付近の攪拌部において, FSW により 5052 がよ り外側の母材部の硬さよりあ軟化していることがわかる。こ れは 5052 が H34 の加工硬化処理されている材料であり, FSW 攪拌部や熱影響部で入熱により加工ひずみが解放され軟化す るという FSW ではしばしば観察される現象である ${ }^{12), 13)}$ 。Fig. 4 (a) 硬さ分布図の攪拌部 5052 側には，90 HV 以上の硬い領 域が島状に出現していた。これは，マクロ組織から ADC12の 材料であると考えられる。著者ら ${ }^{9)}$ は, 同様な分布を EPMA による元素分析において 5052 中に $\mathrm{ADC} 12$ が分布しているむ のであることを確認しており，オニオンリングの一部である と考えられた。このような状態は内部欠陥むなく攪拌部で両 側の材料がよく攪找された状態であると言える。

Fig. 5 に5052/ADC12 の配置の接合継手断面硬さ分布図を, 接合速度 125 $2000 \mathrm{~mm} / \mathrm{min}$ の順に並べて示す。Fig. 6 は Fig. 5 の $\mathrm{AS}$ と RS の材料を入替えた $\mathrm{ADC} 12 / 5052$ の配置の接合継 手断面硬さ分布図である。 FSW では, RS の材料が攪拌部上 部において AS 側に，また攪拌部中心から下部においては AS の材料が RS 側に流動するという現象が見られる。特に低接 合速度の硬さ分布図から，その様子が見られた。この攪拌部 両側材料の流動現象は接合速度の増加に伴い, 左右材料の相 互の入り込み範囲が狭くなっている傾向があることがわかっ た。すなわち, $125 \mathrm{~mm} / \mathrm{min}$ の条件で約 $3 \mathrm{~mm}$ の材料の入り込 みがあったのに対し， $2000 \mathrm{~mm} / \mathrm{min}$ の条件では約 $2 \mathrm{~mm}$ の入り 込みに留まっていた。これは，接合速度が大きくなると材料 の温度が低くなり流動がしにくくなることと, 単位体積に注 目したときにその体積が覺拌されている時間が短くなること が複合していると考えられる。

次に, Fig. 5 において, 5052 側の攪拌部の軟化程度を比較 する。 5052 は H34 材であるので, FSW により攪拌部および 熱影響部が軟化した。母材部の硬さが約 $75 \mathrm{HV}$ であるのに対 して，攪拌部では $60 \mathrm{HV}$ 以下まで低下した場所むあった。そ の軟化の程度は, 接合速度の増加に伴い, 減少する傾向が見 られた。また, 軟化部分の面積屯接合速度の増加に伴って減 少する傾向が見られた。

上記の軟化傾向は, AS と RS の材料を入替えた配置 Fig. 6

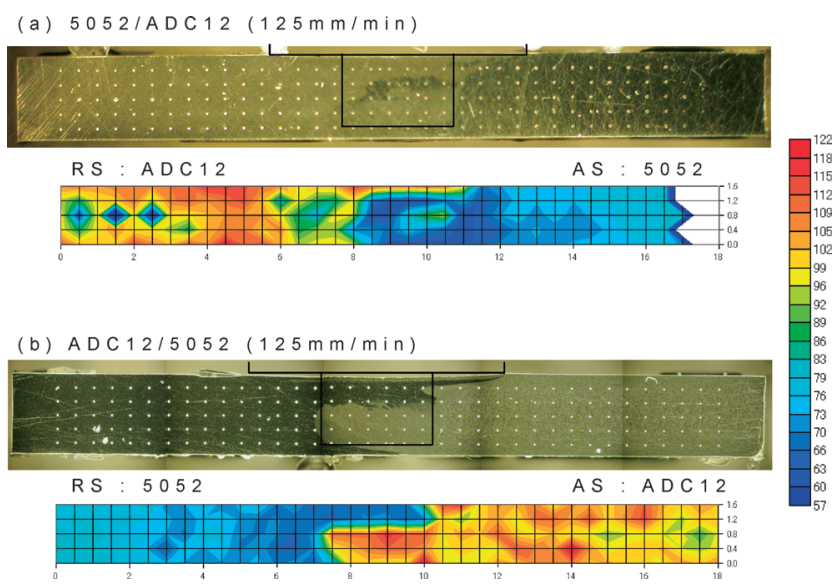

Fig. 4 Optical macrographs and hardness distribution chart of the joints FSWed at a traveling speed of 125 $\mathrm{mm} / \mathrm{min}$. (a) 5052/ADC12 and (b) ADC12/5052.

RS: $A D C 12$

A S : 5052

(a) $125 \mathrm{~m} \mathrm{~m} / \mathrm{min}$

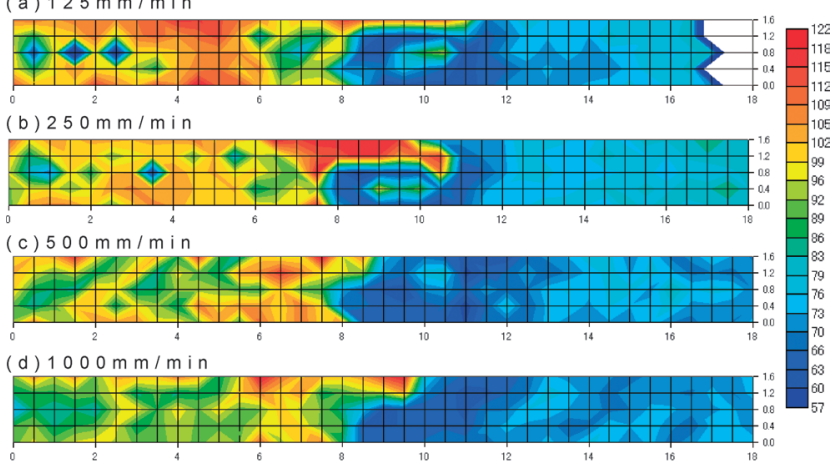

(e) $1500 \mathrm{~mm} / \mathrm{m} \mathrm{in}$

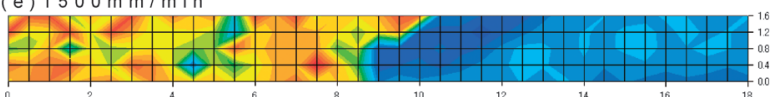

(f) $2000 \mathrm{~mm} / \mathrm{min}$

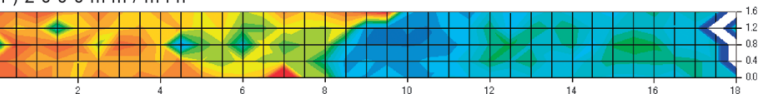

Fig. 5 Hardness distribution chart of 5052/ADC12 FSWed joint at traveling speeds from 125 to $2000 \mathrm{~mm} / \mathrm{min}$.

RS: 5052

(a) $125 \mathrm{~m} \mathrm{~m} / \mathrm{min}$

AS : A D C 12

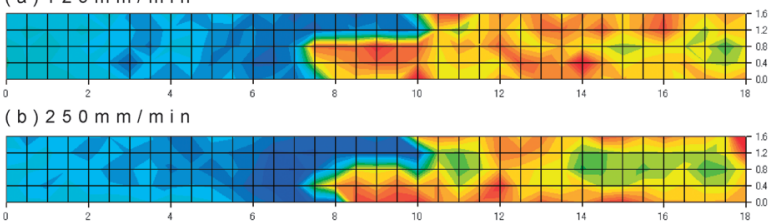

(c) $500 \mathrm{~mm} / \mathrm{min}$

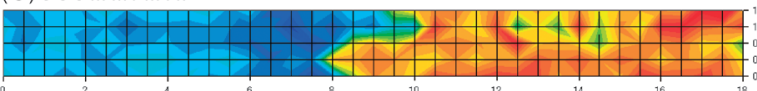

(d) $1000 \mathrm{~m} \mathrm{~m} / \mathrm{min}$

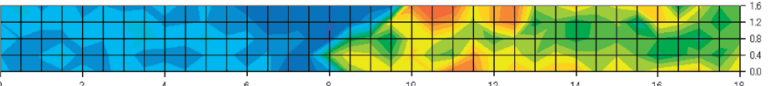

(e) $1500 \mathrm{~mm} / \mathrm{m}$ i n

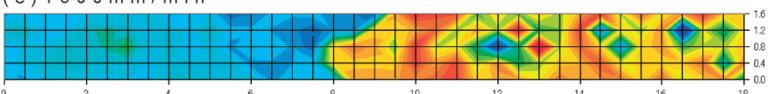

(f) $2000 \mathrm{~m} \mathrm{~m} / \mathrm{min}$

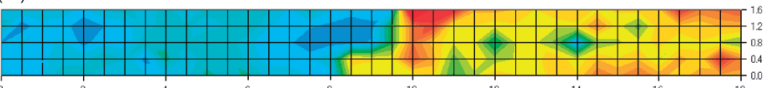

Fig. 6 Hardness distribution chart of ADC12/5052 FSWed joint at traveling speeds from 125 to $2000 \mathrm{~mm} / \mathrm{min}$. 


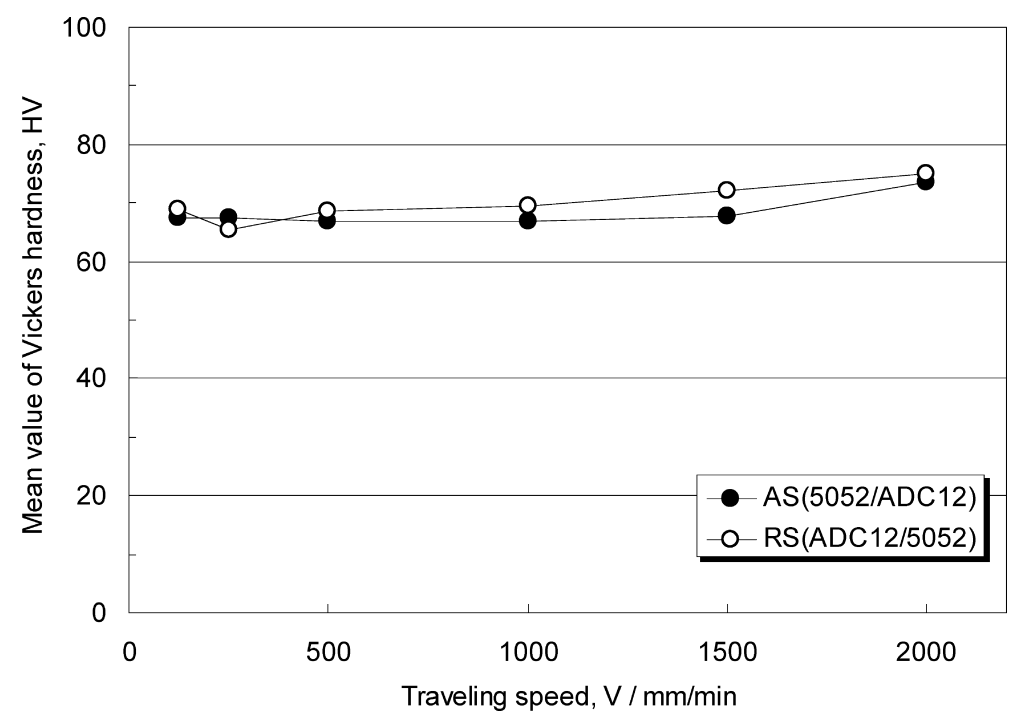

Fig. 7 Average Vickers hardness in stir zone as a function of traveling speed.

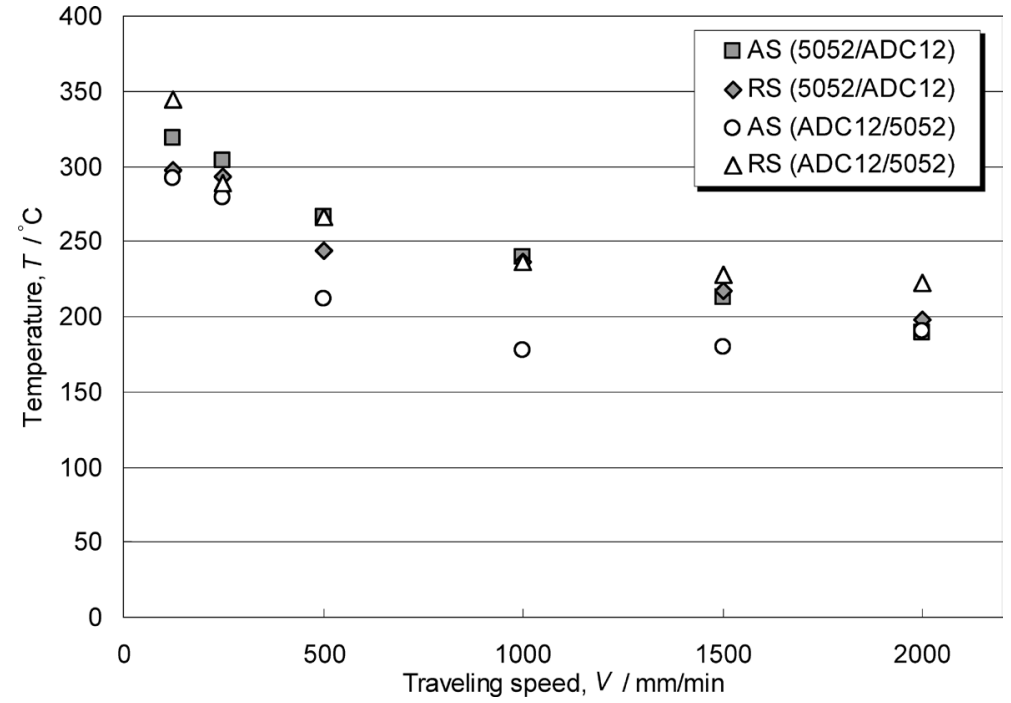

Fig. 8 Temperature at positions $5 \mathrm{~mm}$ away from butt line of joints as a function of traveling speed.

においても同様である。すなわち，接合速度が低速になるに したがって，攪拌部 5052 側の軟化の程度が大きく，かつ，軟 化の範囲屯広くなった。材料配置の違いは，覺拌の程度に現 れている。詳細は後述する。Fig. 7 は，接合中心から $\pm 3 \mathrm{~mm}$ の攪拌部における 5052 の平均硬さと接合速度との関係を示 す。 $1000 \mathrm{~mm} / \mathrm{min}$ 以下の接合速度ではほぼ一定の值ともみな せるが，全速度範囲を見ると，右上がりの傾向であると言え る。引張試験による材料のネッキングと接合速度の関係は, ここで述べた 5052 の軟化具合に関係していることがわかっ た。また, 両材料の入り込みは, 引張試験の際, 相対的に硬 い材料である ADC12 が相対的に軟らかい 5052 の変形を拘束 している可能性が示唆される。前述 Fig. 3 の接合速度 125 $\mathrm{mm} / \mathrm{min}$ の条件での幅方向の絞りが，5052/ADC12 の配置で $15.4 \%, \mathrm{ADC} 12 / 5052$ の配置で $18.5 \%$ という数字にも現れてい る。この, 接合速度が遅い条件で軟化の程度が大きいという 傾向は, FSW 時の入熱量, 材料の上昇温度によるものと考 えられる。既報 ${ }^{10)}$ において 5052/ADC12 配置の攪拌部温度は 接合速度 $125 \mathrm{~mm} / \mathrm{min}$ において約 $510^{\circ} \mathrm{C}, 500 \mathrm{~mm} / \mathrm{min}$ において 約 $460^{\circ} \mathrm{C}$ と測定された。すなわち, 単位体積あたりの入熱量
が多く, 材料の温度上昇が大きい低接合速度の FSW 条件で, 5052 の軟化の程度が大きくなったと考えられる。この攪拌部 5052 の軟化の傾向は, Fig. 3 引張試験片破断部のネッキング の傾向と一致し, 引張強さや破断伸び值に影響した。ネッキ ングにより伸びた継手，すなわち，FSWによって軟化した継 手は，引張試験中に加工硬化し引張強さが増加した。一方， 伸びていない継手，すなわち，FSWによって軟化していない 継手は, 加工硬化が少ない。結果として, 両者の引張強さが FSW 速度に依存せずほぼ同じ值となったといえる。しかしな がら, 実用の観点から両継手の特性が異なることは明らかで ある。

次に, Fig. 5 および Fig. 6 で示した配置の違う両者を同接合 速度で比較する。Fig. 5 の 5052/ADC12 の配置 $125 \mathrm{~mm} / \mathrm{min}$ お よび $250 \mathrm{~mm} / \mathrm{min}$ の断面において, AS : 5052 側の攪拌部に硬 さが高い ADC12 材の現れている場所が存在したが, Fig. 6 の $\mathrm{ADC} 12 / 5052$ の配置では Fig. 5 に見られた薄片状の ADC12 は 見られなかった。これは，5052/ADC12の攪拌部に比べて， ADC12/5052 は両材料の流動が少なかったと言える。さらに, 1000, $1500 \mathrm{~mm} / \mathrm{min}$ の条件の攪拌部を比較すると, Fig. 5 の 
5052/ADC12 の配置の方が，5052 側の軟化している範囲が広 い。これは，次節に述べるように，AS/RSの材料の配置に よって，攪拌の程度や材料の温度が異なることを示唆してお り，異種材料の FSW においては材料配置が重要になる場合 があると考えられる。

\section{3 攪找部付近の温度}

Fig. 8 に接合中心から $5 \mathrm{~mm}$ 離れた位置での温度と接合速 度との関係を示す。5052/ADC12 の配置では，AS と RS の 5 $\mathrm{mm}$ 離れた位置での温度差はほとんどみられなかった。これ に対して, ADC12/5052の配置では, RSの 5052 の方が, AS の $\mathrm{ADC} 12$ と比べて温度が高く, 約 $50^{\circ} \mathrm{C}$ 程度高い温度になっ た接合条件もあった。これらの条件では RSでばりが発生し 熱電対を覆っていた。このばりは攪拌部で高温に熱せられた 材料であり，測定温度が上昇する方向に作用したと考えられ る。接合速度による变化傾向を見ると，接合速度が遅いほど 高温になっていた。これは，攪找部 5052 の硬さ分布の接合 速度依存傾向と一致する。

また，それぞれの接合速度で5052/ADC12の AS:5052 と， $\mathrm{ADC} 12 / 5052$ の RS:5052 の温度を比較すると，どの接合速度で あそれぞれほぼ等しい值となった。著者ら10）は異種材の接 合は AS の材料同士を接合したときの温度に近いことを確認 しており，入熱量が等しいと仮定すると，比熱の小さい 5052 の方が温度は高くなった。ADC12/5052の RS:5052 の温度が高 温のばりによって実際の材料の温度より屯若干高めに測定さ れたと仮定すると，5052/ADC12 の配置の方が ADC12/5052 の 配置よりも 5052 の温度が高い結果となった。5052/ADC12 の 配置の方が $\mathrm{ADC} 12 / 5052$ の配置よりも軟化しているという硬 さ分布の傾向に一致することがわかった。

\section{4. 結言}

アルミニウム合金ダイカストとアルミニウム合金展伸材の FSW 継手の硬さ測定を行い, 温度や引張強さとの関係を検 討した結果，以下の結論を得た。

(1) $125 \mathrm{~mm} / \mathrm{min}$ から $2000 \mathrm{~mm} / \mathrm{min}$ の接合速度範囲におい て, 接合継手の引張強さは FSW 速度の影響はほとんどなく,
5052 母材強度の約 $88 \%$ でほぼ一定の約 $230 \mathrm{MPa}$ であった。

(2) $125 \mathrm{~mm} / \mathrm{min}$ から $2000 \mathrm{~mm} / \mathrm{min}$ の接合速度範囲におい て，攪拌部 5052 の軟化の程度は，低接合速度の方が軟化し ていることがわかった。軟化が激しい低接合速度においては， 材料の流動性がよく, 高接合速度と比較してより異材の攪挥 領域が広くなった。

（3）攪拌部 5052 の軟化の傾向は, 引張試験片破断部の ネッキングの傾向と一致し, 引張強さや破断伸び值に影響し た。ネッキングにより伸びた継手は引張試験中に加工硬化し 引張強さが増加し，伸びていない継手は加工硬化が少ない。 以上のように, FSW 条件で継手の特性が異なり, 必ずしも継 手を引張強さのみで評価できない。

\section{参 考 文 献}

1) W. M. Thomas, E. D. Nicholas, J. C. Needhan, M. G. Murch, P. TempleSmith and C. J. Dawes: International Patent Application PCT/ GB92/02203 and GB Patent Application 9125978.8, UK Patent Office, London, December 6, 1991

2）溶接学会：摩擦攪拌接合, 産報出版, (2006), 12-31.

3）時末 光：FSW の基礎と応用，日刊工業新聞社，（2005）

4）摩擦圧接協会：摩擦接合技術，日刊工業新聞社，（2006）, 238-246.

5) Z. Y. Ma, R. S. Mishra and M. W. Mahony: Scripta Mater., 51 (2004), 931-935.

6) W. B. Lee, Y. M. Yeon and S. B. Jung: Scripta Mater., 49 (2003), 423428

7) K. Okamoto, S. Hirano, M. Inagaki: Sheet Metal Welding Conference XI, (2004), 1-7.

8）立野高寛, 津村卓也, 駒崎 徹, 赤松勝也, 中田一博：鋳造工 学, 78 (2006), 389-395.

9) M. Kokubo, S. Kazui, T. Kaneuchi, Y. Takayama, H. Kato and S. Hirano: Materials Science Forum, Vols. 539-543 (2007), 3789-3794.

10）小久保正史, 高山善匡, 和井伸一, 金内良夫, 加藤 一, 平野 聡：軽金属, 57 (2007), 511-517.

11）軽金属学会：アルミニウムの組織と性質，(1991），454-533

12) Y. S. Sato, H. Kokawa, M. Enomoto and S. Jogan: Metall. Mater. Trans. A, 30A-9 (1999), 2429-2437.

13) H. Liu, H. Fujii, M. Maeda and W. Tang: Scripta Mater., 52-6 (2005), 491. 